\title{
Anti-Inflammatory, Immunomodulatory, and Heme Oxygenase-1 Inhibitory Activities of Ravan Napas, a Formulation of Uighur Traditional Medicine, in a Rat Model of Allergic Asthma
}

\author{
Sajida Abdureyim, ${ }^{1}$ Nurmuhammat Amat, ${ }^{2}$ Anwar Umar, ${ }^{2,3}$ Halmurat Upur, ${ }^{2}$ \\ Benedicte Berke, ${ }^{3}$ and Nicholas Moore ${ }^{2,3}$ \\ ${ }^{1}$ First Affiliated Hospital, Xinjiang Medical University, Xinjiang 830011, China \\ ${ }^{2}$ Department of Traditional Uighur Medicine, Xinjiang Medical University, Xinjiang 830011, China \\ ${ }^{3}$ Department of Pharmacology, Universite de Bordeaux, 33076 Bordeaux, France
}

Correspondence should be addressed to Halmurat Upur, halmurat@263.net and

Nicholas Moore, nicholas.moore@pharmaco.u-bordeaux2.fr

Received 9 May 2010; Revised 1 July 2010; Accepted 13 August 2010

Copyright ( $) 2011$ Sajida Abdureyim et al. This is an open access article distributed under the Creative Commons Attribution License, which permits unrestricted use, distribution, and reproduction in any medium, provided the original work is properly cited.

Ravan Napas (RN) is a traditional formula used to treat pulmonary symptoms and diseases such as coughing, breathing difficulty, and asthma in traditional Uighur medicine. The purpose of this study was to investigate the anti-inflammatory, and immunomodulatory activity of RN in a well-characterized animal model of allergic asthma. Rats were sensitized with intraperitoneal (ip) ovalbumin (OVA) and alum, and then challenged with OVA aerosols. The asthma model rats were treated with RN; saline- and dexamethasone- (DXM-) treated rats served as normal and model controls. The bronchoalveolar lavage fluid (BALF) cellular differential and the concentrations of sICAM-1, IL-4, IL-5, TNF- $\alpha$, INF- $\gamma$, and IgE in serum were measured. Lung sections underwent histological analysis. The immunohistochemistry S-P method was used to measure the expression of ICAM-1 and HO- 1 in the lung. RN significantly reduced the number of inflammatory cells in BALF and lung tissues, decreased sICAM-1, IL-4, IL-5, TNF- $\alpha$, and IgE in serum, and increased serum INF- $\gamma$. There was a marked suppression of ICAM- 1 and HO- 1 expression in the lung. Our results suggest that RN may have an anti-inflammatory and immuneregulatory effect on allergic bronchial asthma by modulating the balance between Th1/Th2 cytokines.

\section{Introduction}

Asthma is a major public health problem worldwide. Asthma morbidity and mortality have increased in the recent decades [1]. Bronchial asthma is a chronic inflammatory disorder of the airways characterized by airflow obstruction, airway inflammation, persistent airway hyperresponsiveness (AHR), and airway remodeling [2]. Increasing evidence suggests that many cells and cellular elements play prominent roles in the pathogenesis of allergic asthma [3, 4]. This pathogenesis is mediated by nonspecific infiltration by various inflammatory cells such as eosinophils, T-lymphocytes, macrophages, neutrophils, and epithelial cells $[5,6]$. In addition, symptoms are mediated by a wide range of compounds such as histamine, cytokines, and cyclo-oxygenase and lipoxygenase products [7].
A variety of cytokine-bronchial cell interactions play an important role in normal host defense as well as in the pathogenesis of inflammatory airway disorders such as asthma, acute and chronic bronchitis, and bronchiectasis [8]. Increasing clinical and experimental evidence suggests that an imbalance between Th1 and Th2 leads to the clinical expression of allergic disease including asthma. The Th2 cytokines such as IL-4, IL-5, and TNF- $\alpha$ become overly abundant when activated by $\mathrm{CD}_{4}{ }^{+} \mathrm{T}$ cells relative to Th1 cytokine (IFN- $\gamma$ ), and this is seen to play a central role in the pathogenesis of allergic asthma [9-13]. Antigeninduced IgE production, airway inflammation, and airway hyperresponsiveness have been well documented in patients with allergic asthma and in animal models [14-18].

Adhesion of inflammatory cells to the bronchial epithelium is the crucial step in inducing bronchial inflammation 
TABLe 1: Plants contained in Uighur herbal formula: Ravan Napas.

\begin{tabular}{lcccc}
\hline Latin name & Family & Part used & Vulgar name & Uighur name \\
\hline Hyssopus cuspidatus Boriss. & Lamiaceae & Aerial part & Hyssop & Zupa \\
Foeniculum vulgare Mill. & Apiaceae & Root & Fennel & Arpa Badian \\
Carthamus tinctorius L & Asteraceae & Seed & Safflower & Qamgur Uruki \\
Brassica rapa L & Brassicaceae & Seed & Turnip mustard & Binapxa Uruki \\
Malva verticillata L. & Malvaceae & Seed & Mallow & Katira \\
Astragalus mongholicus Bunge & Fabaceae & Root & Vetch & Qilan \\
Ziziphus jujuba Mill & Rhamnaceae & Fruit & Red date & Gul binapxa \\
Viola tianshanica Maxim & Violaceae & Aerial part & &
\end{tabular}

in asthma. ICAM-1 participates by inducing the adhesion to and migration of the inflammatory cells through the endothelium [19]. Upregulation of ICAM-1 in epithelial and endothelial cells is believed to be a hallmark of asthma in adults [20, 21]. ICAM-1 is shed by the cell and can be detected in plasma, serum, or bronchoalveolar lavage fluid (BALF) in a soluble form, sICAM-1. The role of heme oxygenase $(\mathrm{HO})$ in pulmonary medicine is a rapidly emerging field [22-24]. HO-1 can be induced by various stimuli such as stress, endotoxins, hypoxia, and so forth. The highly active synthesis of $\mathrm{HO}-1$ proteins has been found in bronchial epithelial cells, lung tissues, lung macrophages and type II lung epithelial cells of asthma models [25, 26]. Expression of the HO-1 is increased within the lung tissue in allergic airway inflammation, and overexpression of HO-1 could enhance allergic airway inflammation [27, 28].

The treatment of asthma has been improved by the implementation of management guidelines in recent years, with further development in the studies that identify the mechanisms of asthma. Inhaled corticosteroids and $\beta$-2agonists are used as the first line of treatment of asthma, reducing airway inflammation and bronchial constriction effectively. However, the effects of these drugs are not always satisfactory in clinical practice because of local or systemic side effects [29]. Therefore, there is a place for new or alternative approaches to the control of asthma such as those found in complementary and alternative medicine (CAM), and especially in traditional medical systems. With the development of modern pharmacological and molecular biology techniques, studying the mechanisms of CAM in treating asthmatic diseases is increasingly important and potentially useful.

CAM approaches include those such as traditional Uighur medicine (TUM), which is used in Xinjiang Uighur Autonomous Region of China. From the principle of TUM, the pathogenesis of asthma is due to the stimulation of Abnormal Hilit (the fluids involved as the basis of traditional Uighur medicine) in the lung tissue, which weakens natural power factors and induces inflammation. Ravan Napas (RN) is a TUM formula, which has been used for more than 2000 years [30]. $\mathrm{RN}$ is a herbal concoction, which has been used under TUM principles with the ultimate goal of relief from wheezing and reduction of frequency of attacks in asthmatic patients. Physicians in the TUM system use RN that has been manufactured into granules to remove the
Abnormal Hilit and to boost the body's natural power. RN is regarded as a potent tonic to increase energy levels and stimulate the immune system. Several studies have focused on its immune-regulating properties, and $\mathrm{RN}$ has been shown to increase human lymphocyte proliferation, and immunoglobulin production in normal mice [31]. Plants related to those used in $\mathrm{RN}[32,33]$ and other plants used in traditional Asiatic medicines [34-40] have been shown to have an effect on immunomodulation and inflammatory responses in experimental asthma. However, RN has not yet been investigated for application to allergic diseases. We used the ovalbumin- (OVA-) induced asthmatic rat model to evaluate possible mechanisms of RN on inflammation and on systemic immune responses, using OVA-induced BALF cell proliferation, cytokines production, and expression of ICAM-1 and HO-1 in the lung.

\section{Methods}

2.1. RN Preparation. The composition of $\mathrm{RN}$ is listed in Table 1 and the chemicals identified in these herbs are listed in Table 2. The constituent plants were purchased from Xinjiang Autonomous Region Traditional Uighur Medicine Hospital (Urumqi, China) and were authenticated by associate chief pharmacist Anwar Talip. In accordance with the protocol of preparation, $1 \mathrm{~kg}$ dried herb powder was soaked in $10 \mathrm{~L}$ of warm distilled water for 12 hours and boiled for 1 hour. The extract was filtered and concentrated under reduced pressure and low temperature $\left(60^{\circ} \mathrm{C}\right)$ on a rotary evaporator, dried in vacuum conditions, and stored in the refrigerator. The yield of the extract was found to be $22.1 \%$.

2.2. Animals and OVA-Induced Asthmatic Rat Model. Male Wistar Rats, weighing 200-250g were purchased from Xinjiang Medical University Animal Centre. The animals were housed in stainless steel cages in the Good Laboratory Practices-compliant laboratory of the Xinjiang Traditional Uighur Medicine Institute. The room temperature $\left(22 \pm 1^{\circ} \mathrm{C}\right)$ and humidity $(55 \pm 10 \%)$ were controlled automatically. The experimental procedures were approved by the guidelines of the Animal Care and Use Committee of Traditional Uighur Medicine Institute, Xinjiang Uighur Autonomous Region. Induction of asthma in rats has been described previously [41]. Rats were immunized with an intraperitoneal injection of a suspension containing $40 \mathrm{mg}$ of OVA (Sigma Chemical 


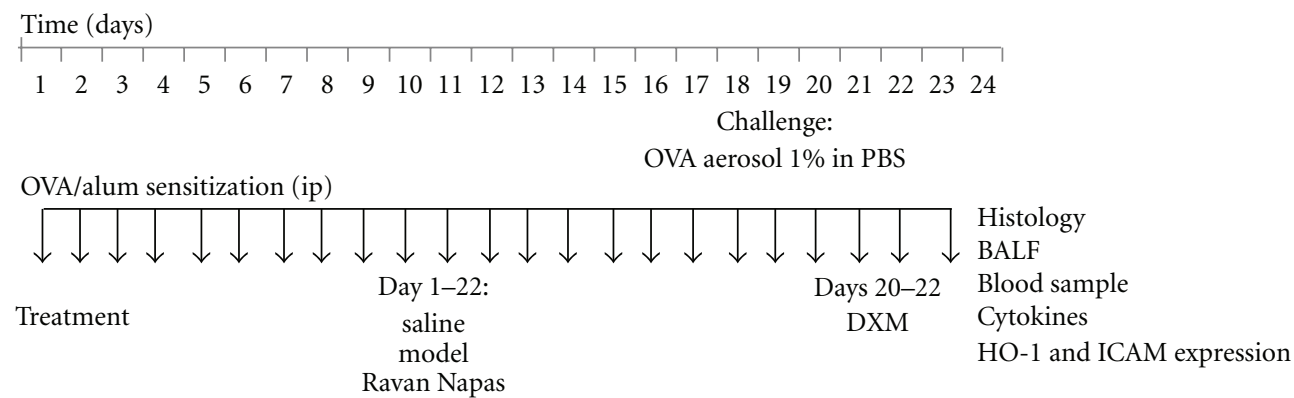

FIGURE 1: Experimental protocol. Rats were immunized with intraperitoneal injection of a suspension containing $40 \mathrm{mg}$ ovalbumin (OVA) and $2 \mathrm{mg}$ aluminium hydroxide. 15 days after the immunization, rats were challenged by exposure to an aerosol of $1 \%$ OVA in PBS for 20 minutes once daily for 8 consecutive days (days 15 to 22). Three groups were treated for 22 days after sensitization, with saline (controls), $\mathrm{RN} 1$, and RN2 (RN orally at $0.25 \mathrm{~g} / \mathrm{kg}$ or $0.5 \mathrm{~g} / \mathrm{kg}$ per day). DXM group was treated with dexamethasone $10 \mathrm{mg} / \mathrm{kg}$ on days 20,21 , and 22 .

Co., St. Louis, MO, USA) and $2 \mathrm{mg}$ of aluminium hydroxide (Beijing Chemical Reagent Factory). Fifteen days after immunization, rats were challenged by exposure to a $1 \%$ OVA in phosphate-buffered saline (PBS) aerosol once daily during 20 min per day for 8 consecutive days. The challenge was carried out in a half vented metal chamber $(35 \mathrm{~cm} \times$ $25 \mathrm{~cm} \times 15 \mathrm{~cm}$ ) by using an ultrasonic nebulizer, Aerosol flow rate was $3 \mathrm{~mL} / \mathrm{min}$. Control group rats were exposed to nebulised sterile saline using the same method. One day after the last challenge the blood and tissue sample were collected.

2.3. Experimental Groups and Treatments. The rats were divided into five groups (ten rats per group): normal, OVAcontrol, OVA-RN1 group, OVA-RN2 group, and Ova-DXM group. All OVA groups were sensitized and challenged with OVA as described above. (Figure 1) OVA-control rats were administered saline orally for 22 days after first sensitization. OVA-RN1 and OVA-RN2 were two RN dosage treatment groups, administered with $\mathrm{RN}$ orally for 22 days after first sensitization at the dose of $0.25 \mathrm{~g} / \mathrm{kg}(\mathrm{RN} 1)$ and $0.5 \mathrm{~g} / \mathrm{kg}$ (RN2) per day, respectively. Ova-DXM rats were administered Dexamethasone (DXM) on days 20, 21, and 22, before challenge, at the dose of $10 \mathrm{mg} / \mathrm{kg}$.

2.4. Measurement of Serum sICAM-1, IL-4, IL-5, TNF- $\alpha$, INF$\gamma$, and Ige. Rats were anesthetized with an intraperitoneal injection of sodium pentobarbitone $(100 \mu \mathrm{g} / \mathrm{kg})$, blood was collected and centrifuged at $4^{\circ} \mathrm{C}(3000 \mathrm{rpm})$ for $10 \mathrm{~min}$, and the serum was stored at $-80^{\circ} \mathrm{C}$ for measurement of cytokines and IgE. ELISA kits from R\&D Systems were employed for the measurement of sICAM-1, IL-4, IL-5, TNF- $\alpha$, INF- $\gamma$, and IgE.

2.5. BALF Preparation and Cell Differential Counts. After blood collection, the trachea was cannulated and the right bronchi were tied for histological studies. Bronchoalveolar lavage fluid (BALF) was collected by lavaging the left lung via the trachea with $15 \mathrm{~mL}$ of ice-cold PBS. After five lavages, approximately $10 \mathrm{~mL}$ of BALF were recovered and centrifuged at $4^{\circ} \mathrm{C}(1500 \mathrm{rpm})$ for 10 minutes. The cells in the BALF were resuspended in $100 \mu \mathrm{L}$ of PBS for total and relative leukocyte counts using a hemocytometer. The cells in the BALF were resuspended in normal saline after a brief hypotonic exposure to lyse red blood cells, then immediately placed on the hemocytometer, left unmoved for 3-5 minutes, and then counted in 10-square chambers.

2.6. Histological Analysis. After sacrifice, noninflated lungs were removed, fixed with $10 \%$ buffered formalin, and processed in a standard manner. Tissue sections were stained with hematoxylin-eosin and examined microscopically. Peribronchial cells were counted using a five-point scoring system to estimate the severity of leukocyte infiltration. The leukocyte scoring was examined in three independent fields of lung section from each rat. Mean scores were obtained from ten rats. The scoring system was 0 , no cells; 1 , a few cells; 2 , a ring of cells 1 cell layer deep; 3 , a ring of cells $2-4$ cell layers deep; and 4 , a ring of cells more than 4 cell layers deep.

2.7. Immunohistochemistry Analysis. To identify the source of HO- 1 and ICAM-1 positive cells, immunohistochemistry staining was performed. Antibodies were diluted 1:200 with $1 \%$ normal goat serum (NGS) in PBS. Lung sections were sequentially incubated overnight at $4{ }^{\circ} \mathrm{C}$ in the dark with rabbit anti-HO-1 or sheep anti-ICAM-1, followed by biotin-labelled antibody to rabbit IgG or sheep IgG and incubated for $30 \mathrm{~min}$ in streptavidin-peroxide, coloured with 3,3-diaminobenzidine (DAB) then sealed with neutral gum. The expression of ICAM-1 and HO-1 was located in the cytoplasm. Brown-yellow granules were considered as positive expression. The scoring system was the number of the positive staining cells: 0 , no cells; $1,0 \sim 10$ cells; 2 , $11 \sim 24$ cells; 3, $25 \sim 49 ; 4,50 \sim 74$ cells; and 5, >75 cells. All histology and immunohistochemical analyses were done blind to treatment group.

2.8. Statistical Analysis. The statistical significance of any difference was determined by one-way ANOVA followed by Tukey's protected $t$-tests when ANOVA was significant. The data are expressed as mean \pm S.E.M. The SPSS statistical software package (Version 10.0, Chicago, IL) was used for the statistical analysis. 
TABLE 2: Chemical composition of the plants contained in Uighur herbal formula: Ravan Napas.

\begin{tabular}{|c|c|c|}
\hline Plant & Major chemical components & References \\
\hline $\begin{array}{l}\text { H. cuspidatus aerial } \\
\text { part }\end{array}$ & Essential oil: germacrenes B and D, hexadecanoic acid, $(+)$-transcaryophyllene, $(+)$-spathulenol & Ablizl 2009 [42] \\
\hline \multirow{7}{*}{ F. vulgare fruit } & transanethole, $\mathrm{p}$-anisaldehyde, chlorogenic acid, and quercetin-3-O- $\beta$-D-glucuronide & \multirow{7}{*}{$\begin{array}{l}\text { Bilia 2000 [43] } \\
\text { Kitajima } 1998 \\
{[44-46]} \\
\text { Ishikawa } 1998 \\
{[47]} \\
\text { Ishikawa } 1999 \\
{[48]} \\
\text { Kitajima } 1999 \\
{[49]} \\
\text { Ono } 1995[50] \\
\text { Ono } 1996 \text { [51] } \\
\text { De Marino 2007 } \\
{[52]}\end{array}$} \\
\hline & Water-soluble constituents: & \\
\hline & $\begin{array}{l}\text { alkyl glycosides, p-hydroxyphenylpropylene glycol glycosides, phenylpropanoid glycosides, benzyl } \\
\text { alcohol derivative glycosides, phenylethanoid and its glycoside, threo-epoxyanethole glycoside, } \\
\text { fenchane-, norfenchane-type monoterpenoid glycosides, menthane-, thujane-, camphane-type } \\
\text { monoterpenoids, and monoterpenoid alcohols. }\end{array}$ & \\
\hline & $\begin{array}{l}\text { Monoterpene glycosides: } \beta \text {-D-glucopyranosides of (1S,2R,4S)-2,4-dihydroxy-1,8-cineole-2-O, } \\
\text { (1R,4R,6R)-4,6-dihydroxy-1,8-cineole-6-O, (1R,4R,6R)-4,6-dihydroxy-1,8-cineole-4-O, } \\
(1 \mathrm{~S}, 2 \mathrm{R}, 4 \mathrm{R}, 6 \mathrm{~S}) \text {-2,6-dihydroxy-1,8-cineole-2-O and (1S,2R,4S,5R)-2,5-dihydroxy-1,8-cineole-2-O }\end{array}$ & \\
\hline & $\begin{array}{l}\text { Zizybeoside I, icaviside A4, syringin, sinapyl alcohol 1,3'-di-O- } \beta \text {-D-glucopyranoside, } \\
\text { threo-anethole glycol, and erythro-anethole glycol glycosides. }\end{array}$ & \\
\hline & $\begin{array}{l}\text { Stilbene trimers: 11a-O- } \beta \text {-D-glucopyranoside, } 13 \mathrm{~b}-\mathrm{O}-\beta \text {-D-glucopyranoside, } \\
\text { 11a,13b-di-O- } \beta \text {-D-glucopyranoside, } 11 \mathrm{a}, 13 \mathrm{~b}, 13 \mathrm{c} \text {-tri-O- } \beta \text {-D-glucopyranoside of cis-miyabenol C }\end{array}$ & \\
\hline & $\begin{array}{l}\text { Cis-miyabenol C } 11 \mathrm{a}-O-\beta \text {-d-glucopyranosyl- }(1 \rightarrow 6)-\beta \text {-d-glucopyranoside, } c i s \text {-miyabenol C } \\
11 \mathrm{a}, 13 \mathrm{c} \text {-di- } O \text { - } \beta \text {-d-glucopyranoside. }\end{array}$ & \\
\hline \multirow{3}{*}{ C. tinctorius seed } & Serotonin derivatives, lignans, and flavonoids. & \multirow{3}{*}{$\begin{array}{l}\text { Koyama } 2006 \\
{[53]} \\
\text { Kim } 2007[54] \\
\text { Ahmed } 2000 \\
{[55]}\end{array}$} \\
\hline & $\begin{array}{l}\text { Phenolic compounds: matairesinol } 4^{\prime} \text {-o- } \beta \text {-D-glucoside, } 8^{\prime} \text {-hydroxyarctigenin } 4^{\prime}-0-\beta \text {-D-glucoside, } \\
\text { matairesinol, } 8^{\prime} \text {-hydroxyarctigenin, } \mathrm{N} \text {-feruloylserotonin } 5 \text {-O- } \beta \text {-D-glucoside, } \\
\mathrm{N} \text {-(p-coumaroyl)-serotonin-5-O- } \beta \text {-D-glucoside, } \mathrm{N} \text {-feruloylserotonin, } \mathrm{N} \text {-(p-coumaroyl)serotonin, } \\
\text { luteolin } 7 \text {-O- } \beta \text {-D-glucoside, luteolin, acacetin } 7-\mathrm{O}-\beta \text {-glucuronide, and acacetin }\end{array}$ & \\
\hline & $\begin{array}{l}\text { Acacetin } 7-\mathrm{O}-\beta \text {-D-apiofuranosyl- }\left(1^{\prime} \rightarrow 6^{\prime}\right)-\mathrm{O}-\beta \text {-D-glucopyranoside together with previously } \\
\text { isolated kaempferol } 7 \text {-O- } \beta \text {-D-glucopyranoside, acacetin } 7-\mathrm{O}-\alpha \text {-L-rhamnopyranoside, and } \\
\text { acacetin. }\end{array}$ & \\
\hline B. rapa seed & Isothiocyanates: 3-butenyl isothiocyanate. & $\begin{array}{l}\text { Taveira } 2009 \\
{[56]}\end{array}$ \\
\hline M. verticillata seed & $\begin{array}{l}\text { Polysaccharides: } \beta \text {-1,3- and } \beta \text {-1,6-linked D-galactosyl residues acidic polysaccharide (MVS-VI) } \\
\text { and } \beta \text {-1,3-linked D-glucose, and D-galactose residues neutral polysaccharide (MVS-I). }\end{array}$ & $\begin{array}{l}\text { Tomoda } 1992 \\
{[57]} \\
\text { Shimizu } 1991 \\
{[58]}\end{array}$ \\
\hline \multirow{6}{*}{ A. mongholicus root } & Triterpene saponins, isoflavonoids, and polysaccharides. & \multirow{6}{*}{$\begin{array}{l}\text { Zhang } 2007[59 \\
\text { Chu } 2010[60] \\
\text { Han } 2007[61] \\
\text { Bian } 2006[62] \\
\text { Yu } 2005[63] \\
\text { Wang } 2008[64] \\
\text { Subarnas } 1991 \\
{[65]} \\
\text { Shimizu } 1991 \\
{[66]} \\
\text { Yan } 2005[67]\end{array}$} \\
\hline & $\begin{array}{l}\text { Methanolic extract: cyclolanostane-type saponins including } 8 \text { astragaloside malonates, and } \\
\text { malonylastragaloside I. }\end{array}$ & \\
\hline & $\begin{array}{l}\text { Astragalosides I, II, IV, acetylastragaloside I, isoastragaloside I isoastragaloside II, } \\
\text { astramembrannin II, afrormosin, calycosin, calycosin-7-O- } \beta \text {-D-glucoside, daucosterol } \\
\text { formononetin, formononetin-7-O- } \beta \text {-D-glucoside, } \\
\text { formononetin-7-O- } \beta \text {-D-glucoside-6"'-O-malonate, } \\
2^{\prime}, 4^{\prime} \text {-dimethoxy-3'-hydroxyisoflavan-6-O- } \beta \text {-glucopyranoside, } \\
(6 \mathrm{aR}, 11 \mathrm{aR}) 9,10 \text {-dimethoxypterocarpan-3-O- } \beta \text {-D-glucoside, } \\
(6 \mathrm{aR}, 11 \mathrm{aR}) 3,9 \text {-dimethoxy-10-hydroxypterocarpan, }(3 \mathrm{R}) 8,2^{\prime} \text {-dihydroxy-7,4' -dimethoxyisoflavan, } \\
\text { ononin, pinitol, } \beta \text {-sitosterol. }\end{array}$ & \\
\hline & $\begin{array}{l}\text { Calycosin-7-O- } \beta \text {-D-glucoside, } \\
(6 \mathrm{aR}, 11 \mathrm{aR})-3 \text {-hydroxy-9,10-dimethoxypterocarpan-3-O- } \beta \text {-D-glucoside, and } \\
\text { 3,9-di-O-methylnissolin } \\
\text { 4-hydroxy-5-hydroxymethyl- }[1,3] \text { dioxoian-2,6'-spirane- } 5^{\prime}, 6^{\prime}, 7^{\prime}, 8^{\prime} \text {-tetrahydro-indolizine- } 3^{\prime} \text { - } \\
\text { carbaldehyde } \\
\text { (HDTIC-1 and -2). }\end{array}$ & \\
\hline & $\begin{array}{l}\text { Isoflavanoids: } 7 \text {-O-methylisomucronulatol, isomucronulatol 7,2'-di-O-glucoside, } \\
5^{\prime} \text {-hydroxyisomucronulatol } 2^{\prime}, 5^{\prime} \text {-di-O-glucoside, and } \\
\text { (3R)-7,2' -dihydroxy- } 3^{\prime}, 4^{\prime} \text {-dimethoxyisoflavan-7-O- } \beta \text {-D-glucoside } \alpha \text {-arabino- } \beta \text {-3,6-galactan-type } \\
\text { acidic polysaccharide }\end{array}$ & \\
\hline & Lectin & \\
\hline
\end{tabular}


TABLE 2: Continued.

\begin{tabular}{|c|c|c|}
\hline Plant & Major chemical components & References \\
\hline \multirow{3}{*}{ Z. jujube fruit } & Water and ethanol extracts: & \multirow{3}{*}{$\begin{array}{l}\text { Guo 2009 } \\
{[68-70]} \\
\text { Pawlowska } 2009 \\
{[71]}\end{array}$} \\
\hline & $\begin{array}{l}\text { Terpenoids: ceanothic acid, alphitolic acid, zizyberanal acid, zizyberanalic acid, zizyberanone, } \\
\text { epiceanothic acid, ceanothenic acid, betulinic acid, oleanolic acid, ursolic acid, } 2 \alpha \text {-hydroxyursolic } \\
\text { acid and zizyberenalic acid, } \\
(2 \mathrm{~S}, 3 \mathrm{~S}, 4 \mathrm{R}, 8 \mathrm{E})-2-\left[\left(2^{\prime} \mathrm{R}\right)-2^{\prime} \text {-hydroxy-tetracosanoyl]-8-octadecene-1,3,4-triol and its }\right. \\
\text { 1-O- } \beta \text {-D-glucopyranosyl derivate, maslinic acid, } 3 \beta, 6 \beta \text {-stigmast-4-en-3,6-diol, } \beta \text {-sitosterol, } \\
\text { daucosterol, tetracosanoic acid, and heptadecanoic acid. }\end{array}$ & \\
\hline & $\begin{array}{l}\text { Flavonoids: kaempferol 3-O-robinobioside, kaempferol 3-O-rutinoside, quercetin } \\
\text { 3-O-robinobioside, quercetin 3-O-rutinoside, quercetin 3-O- } \beta \text {-D-xylosyl-(1-2)- } \alpha \text {-L-rhamnoside, } \\
\text { quercetin 3-O- } \alpha \text {-L-arabinosyl-(1-2)- } \alpha \text {-L-rhamnoside, and rutin. }\end{array}$ & \\
\hline $\begin{array}{l}\text { V. tianshanica aerial } \\
\text { part }\end{array}$ & $\begin{array}{l}\text { Daucosterol and flavonoids: isorhamnetin 3-O- } \beta \text {-glucoside, kaempferol, kaempferol } \\
\text { 7-O- } \beta \text {-D-glucopyranoside, kaempferol 3-O- } \beta \text {-D- glucopyranoside, and quercetin. }\end{array}$ & Yu 2009 [72] \\
\hline
\end{tabular}

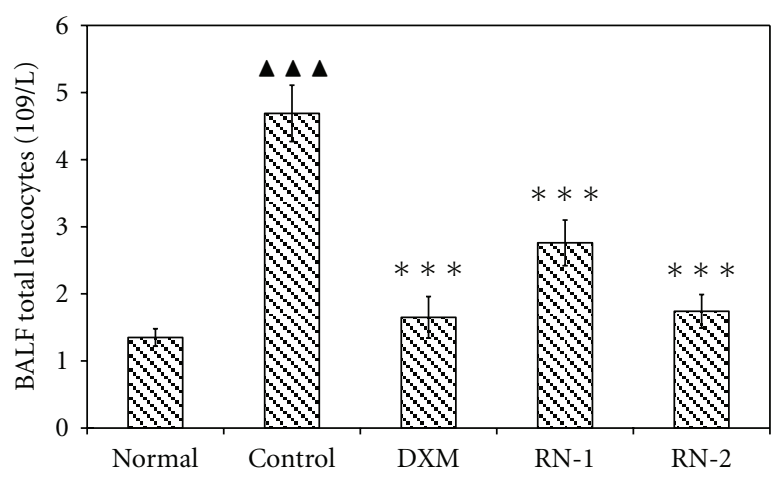

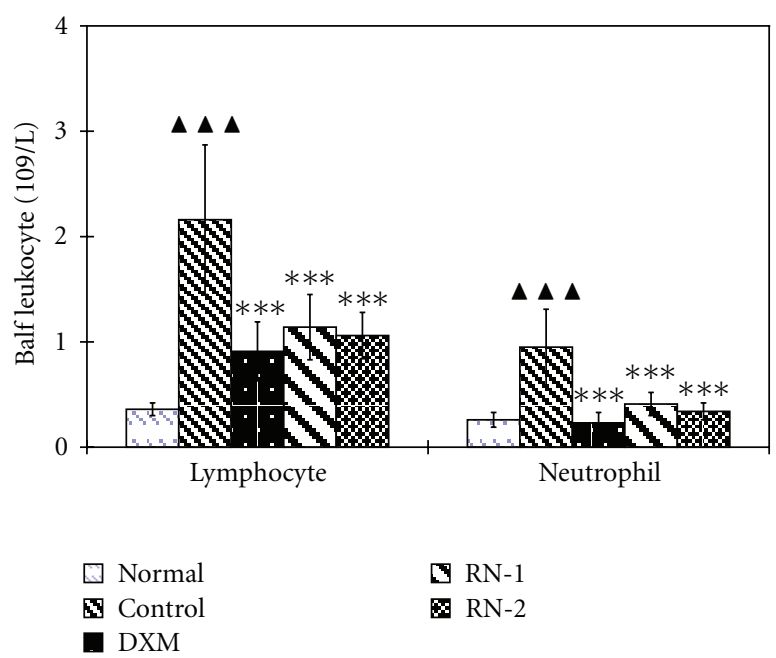

(b)

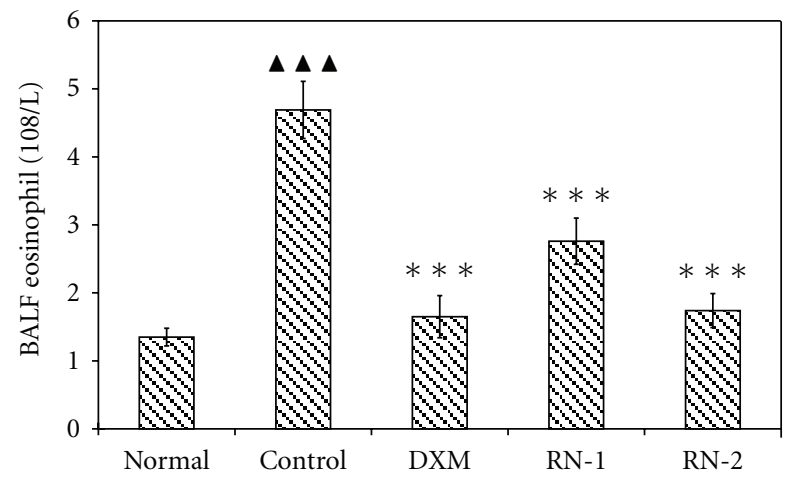

(c)

FIGURe 2: Effect of Ravan Napas (RN) on the recruitment of inflammatory cells in BALF obtained from OVA-induced rat model of asthma. Rat Bronchoalveolar Lavage Fluid (BALF) was harvested during the $24 \mathrm{~h}$ after last OVA challenge. All rats were sensitized with OVA: (a) total leucocytes, (b) lymphocytes and neutrophils, and (c) eosinophils. Normal: rats sensitized with OVA and challenged with saline. Control: rats sensitized and challenged with OVA. DXM: OVA-sensitized and challenged rats treated with Dexamethasone (10 mg/kg). RN-1: OVAsensitized and challenged rats treated with RN $(0.25 \mathrm{~g} / \mathrm{kg} /$ day). RN-2: OVA-sensitized and challenged rats treated with RN (0.5 g/kg/day). Data are expressed as mean \pm S.E.M., $n=10$ rats per treatment group. ${ }^{\boldsymbol{\Delta} \Delta} \boldsymbol{\Delta} P<.01$ versus Normal; ${ }^{* * *} P<.01$ versus Control. 

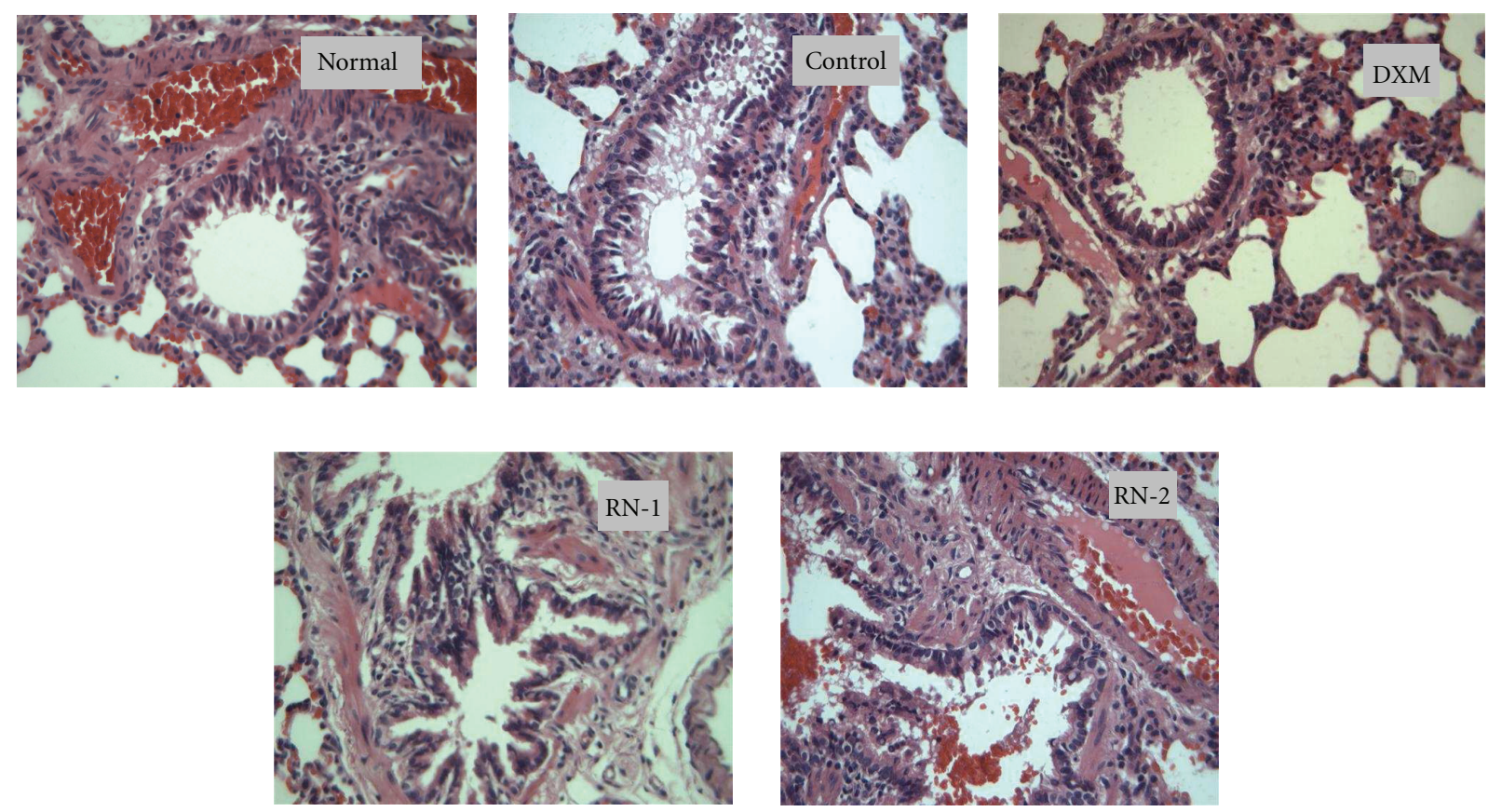

(a)

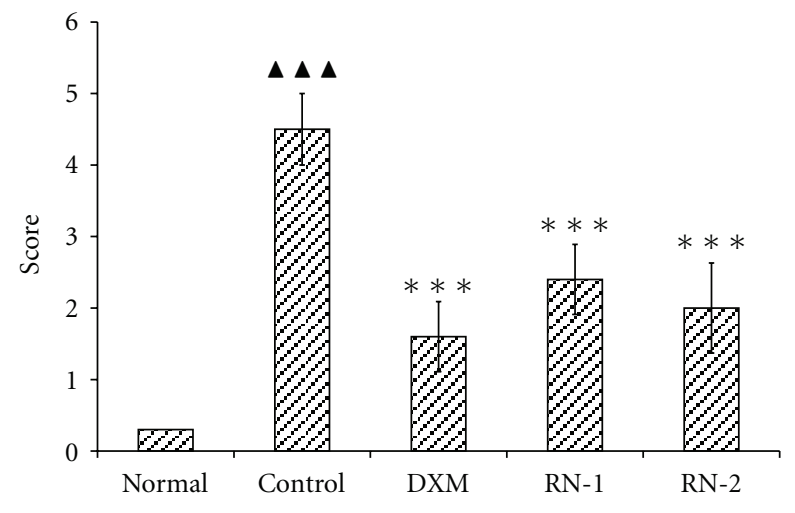

(b)

Figure 3: Effect of Ravan Napas (RN) on pulmonary inflammation in OVA-induced rat model of asthma. Lung tissues were obtained on the day after the last OVA challenge. Tissues were stained with hematoxylin and eosin (H\&E, 400x) (a). The inflammatory cell infiltration in the lung tissues was scored as described in the method section (b). Normal: rats sensitized with OVA and challenged with saline. Control: rats sensitized and challenged with OVA. DXM: OVA-sensitized and challenged rats treated with Dexamethasone (10 mg/kg). RN-1: OVAsensitized and challenged rats treated with $\mathrm{RN}(0.25 \mathrm{~g} / \mathrm{kg} /$ day $)$. RN-2: OVA-sensitized and challenged rats treated with $\mathrm{RN}(0.5 \mathrm{~g} / \mathrm{kg} / \mathrm{day})$. Data are expressed as mean \pm S.E.M., $n=10$ rats per treatment group. ${ }^{\mathbf{\Delta} \Delta} P<.01$ versus Normal; ${ }^{* * *} P<.01$ versus Control.

\section{Results}

3.1. Total Leukocytes and Eosinophils in BALF. RN significantly decreased the number of leukocytes in BALF in comparison with the control group (Figures 2(a) and 2(b) $P<$ .01 versus normal). Differential leukocyte counts showed that RN decreased the number of neutrophils, eosinophils, and lymphocytes in comparison with the control group $(P<.01)$ (Figure 2(c)).

3.2. Pathological Inflammation in Lung Tissue. Rats from each group were autopsied, and sections of the major organs were examined by a pathologist unaware of their origin. No gross or histological abnormalities were observed in tissues other than the lung. As previously described, lungs from normal (sham-treated)/antigen-sensitized/challenged mice contained large numbers of peribronchial and perivascular eosinophils (data not shown). The lung tissue obtained from ovalbumin-induced asthmatic rats was characterized by dense peribronchial inflammation due to leukocyte infiltration and mucus hyperproduction by goblet cells within the bronchi when compared with normal tissue. This inflammation resulted in the narrowing of the bronchi (Figure 3(a)). RN extract significantly reduced the degree of inflammatory cell infiltration $(P<.05)$ (Figure 3(b)). 


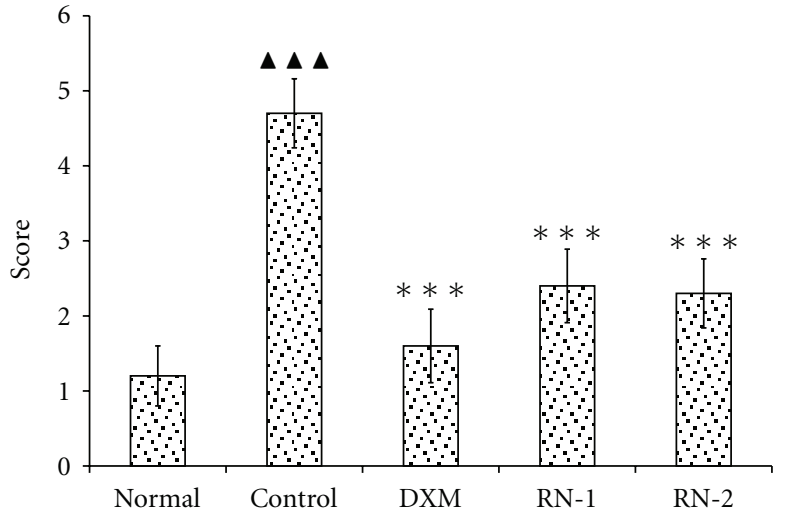

๑ICAM

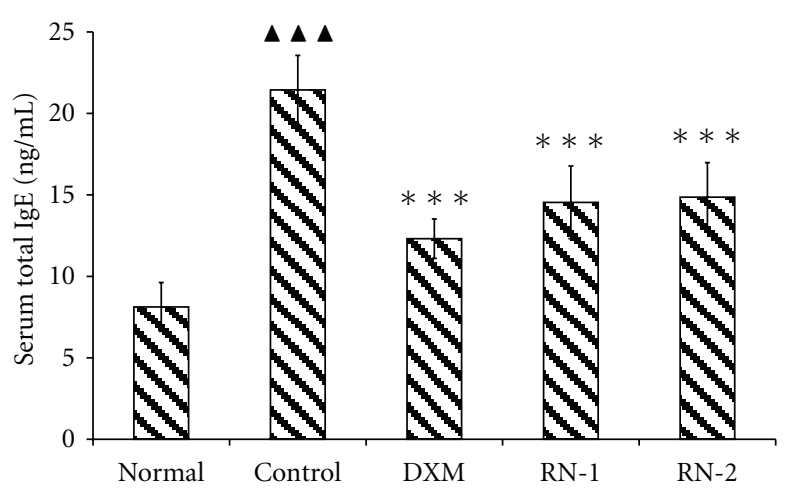

(b)

FIGURE 4: Effect of Ravan Napas (RN) on sICAM-1 and total IgE concentration in serum of OVA-induced rat model of asthma. Blood was sampled and serum obtained $24 \mathrm{~h}$ after last OVA challenge. sICAM-1 and total IgE were measured by ELISA as described in the materials and methods section. (a): sICAM-1 concentrations; (b): IgE concentrations; Normal: rats sensitized with OVA and challenged with saline. Control: rats sensitized and challenged with OVA. DXM: OVA-sensitized and challenged rats treated with Dexamethasone (10 mg/kg). RN-1: OVA-sensitized and challenged rats treated with $\mathrm{RN}(0.25 \mathrm{~g} / \mathrm{kg} /$ day $)$. RN-2: OVA-sensitized and challenged rats treated with RN $(0.5 \mathrm{~g} / \mathrm{kg} /$ day $)$. Data are expressed as mean \pm S.E.M., $n=10$ rats per group. ${ }^{\boldsymbol{\Delta} \Delta \mathbf{\Delta} P}<.01$ versus Normal; ${ }^{* * *} P<.01$ versus Control.

3.3. Serum sICAM-1, IgE, IL-4, IL-5, TNF- $\alpha$, and INF- $\gamma$. The serum concentration of sICAM-1 and total IgE in model group significantly increased following the induction of asthma $(P<.01)$ (Figure 4$)$. OVA induced IL-4, IL-5, TNF- $\alpha$, and IgE elevations in serum (Figure 5). RN inhibited sICAM1 , and IgE increases in serum $(P<.05)$ (Figure 4$)$. IL-4, IL-5, and TNF- $\alpha$ levels in serum were reduced in RN-treated rats compared with model group rats (Figure 5).

The INF- $\gamma$ concentration was reduced by OVA exposure and increased significantly in RN-treated rats. INF- $\gamma$ concentrations after RN1 and RN2 were increased significantly compared with control and normal controls (Figure 5).

3.4. Expression of ICAM-1 and HO-1 in Lung. RN strongly inhibited the increased expression of ICAM-1 and HO-1 following the induction of asthma $(P<.05)$ (Figure 6) when compared with model control rats.

\section{Discussion}

It has been reported that some antiasthma CAM formulas have therapeutic effects on allergic asthma [73-76]. Inhibition of the regional inflammatory response through the reduction of antigen-induced inflammatory cells and inflammatory cytokines production is a main therapeutic objective in the treatment of asthma. In this study, a rat model of allergic asthma was developed, the lung tissues examined, and BAL analysed to assess the effect of RN on airway inflammation in experimental asthma. Pathology analysis documented that 22-day $\mathrm{RN}$ administration reduced the allergic inflammatory infiltration in the lung tissues, reduced OVA-induced sICAM-1, IL-4, IL-5, TNF- $\alpha$, and IgE elevations in serum, and increased INF- $\gamma$ concentration. We also found that RN markedly suppressed increased ICAM-1 and HO-1 expression in lung tissue of allergic asthma rats. Collectively, all of these results demonstrated that $\mathrm{RN}$ is a potent agent in inflammatory pulmonary diseases.

The precise mechanisms of chronic airway inflammation in asthma are incompletely known but are considered to be dependent on the sustained infiltration and activation of many inflammatory cells including lymphocytes, eosinophils, basophils, and macrophages, followed by synthesis and release of a variety of proinflammatory mediators and cytokines $[77,78]$. Th2 lymphocytes are the key orchestrators of this inflammation, initiating and propagating inflammation through the release of their cytokines, IL-4, IL5 , and TNF- $\alpha$ in turn recruiting and activating eosinophils, the effector cells in asthma [79-82]. The infiltration of eosinophils into the airways has been linked to the production of IL-5, which is important for eosinophil proliferation, activation, and migration [83]. IL-4 induces IgE isotype switching in B lymphocytes [84] and mucus production by goblet cells [85], as well as upregulation of the expression of adhesion molecules required for inflammatory cell recruitment [79]. TNF- $\alpha$ is also an important chemoattractant for the recruitment of eosinophils into the lungs $[10,86]$. It is also a potent modulator of immune and inflammatory response.

Migration of leukocytes from circulation into tissue is dependent upon the interaction with adhesion molecules expressed on the cell surface and endothelium. ICAM-1 and its soluble form, sICAM-1, play important roles in the development of airway/lung inflammation in asthma. When inflammation occurs, the expression of ICAM-1 on the bronchial epithelium and lung vascular endothelium is significantly increased and thereby increases the adhesion of 


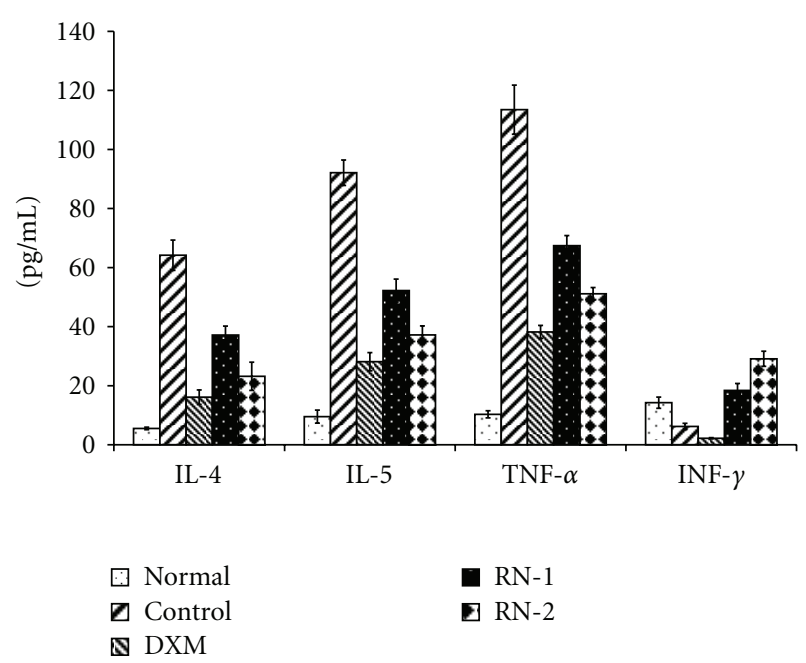

FIgURe 5: Effect of Ravan Napas (RN) on IL-4, IL-5, INF- $\alpha$, and INF- $\gamma$ in serum of OVA-induced rat model of asthma. Blood was sampled and serum obtained $24 \mathrm{~h}$ after last OVA challenge. IL-4, IL-5, TNF- $\alpha$, and INF- $\gamma$ were analyzed by ELISA as described in the materials and methods section. Normal: rats sensitized with OVA and challenged with saline. Control: rats sensitized and challenged with OVA. DXM: OVA-sensitized and challenged rats treated with Dexamethasone $(10 \mathrm{mg} / \mathrm{kg})$. RN-1: OVA-sensitized and challenged rats treated with $\mathrm{RN}(0.25 \mathrm{~g} / \mathrm{kg} / \mathrm{day})$. RN-2: OVA-sensitized and challenged rats treated with RN $(0.5 \mathrm{~g} / \mathrm{kg} /$ day $)$. Data are expressed as mean \pm S.E.M., $n=10$ rats per group. ${ }^{\boldsymbol{\Delta} \boldsymbol{\Delta}} P<.01$ versus Normal; $* * * P<.01$ versus Control.

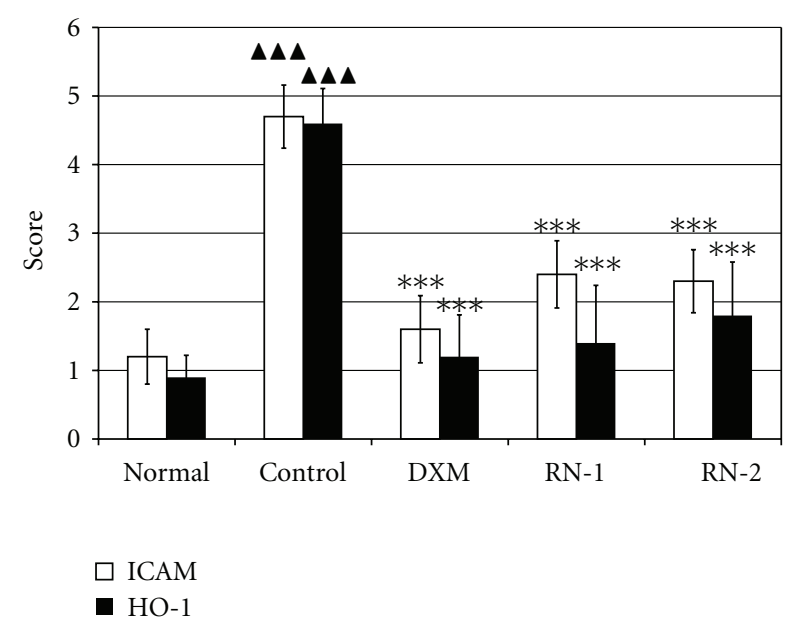

Figure 6: Effect of RN on the expression of ICAM-1 and HO-1 in lung tissue of OVA-induced rat model of asthma. Wistar rat lung tissue was obtained 24 hours after last Ova challenge. Immunohistochemistry was performed as described in materials and methods section. Expression of ICAM-1 and HO-1 in the lung tissues was scored as described in Section 2. Normal: rats sensitized with OVA and challenged with saline. Control: rats sensitized and challenged with OVA. DXM: OVA-sensitized and challenged rats treated with Dexamethasone $(10 \mathrm{mg} / \mathrm{kg})$. RN-1: OVA-sensitized and challenged rats treated with $\mathrm{RN}(0.25 \mathrm{~g} / \mathrm{kg} / \mathrm{day})$. RN-2: OVA-sensitized and challenged rats treated with $\mathrm{RN}(0.5 \mathrm{~g} / \mathrm{kg} /$ day $)$. Data are expressed as mean \pm S.E.M., $n=10$ rats per group. ${ }^{\boldsymbol{\Delta} \Delta} \mathbf{\Delta} P<.01$ versus Normal; $* * * P<.01$ versus Control. eosinophils on the epithelium [87-89]. There is a close correlation between high concentration of sICAM-1 and high expression of ICAM-1 with the severity of asthma in patients and asthmatic rats $[19,89,90]$. Higher concentrations of sICAM-1 in serum and BALF reflect the upregulation of ICAM-1 expression in allergic bronchial asthma, and these high concentrations may contribute to the pathogenesis of atopic bronchial asthma $[91,92]$.

The eosinophil is regarded as a key mediator of the pathology and abnormal physiology of bronchial asthma [93]. It has been suggested that eosinophils contribute to tissue damage $[94,95]$ and airway inflammation. AHR also may play an important role in recruitment of $\mathrm{T}$ cells to the lung during airway allergic responses by modulating chemokine and cytokine production in the lung. In most asthma phenotypes, there are increases in eosinophils in the tissues, blood and bone marrow and, in general, raised numbers correlating with disease severity [96]. Specifically, TNF- $\alpha$ is an important chemoattractant for the recruitment of eosinophils into the lungs $[10,86]$. It is also a potent modulator of immune and inflammatory response. IL5 uniquely and specifically participates in the control of eosinophil production and differentiation [10]. Attenuated synthesis of TNF- $\alpha$ and IL- 5 could therefore relieve allergic responses caused by eosinophils.

Our results showed that serum concentrations of IL4 , IL-5, TNF- $\alpha$, and sICAM- 1 were significantly reduced in allergic rats after $\mathrm{RN}$ administration. In addition, $\mathrm{RN}$ inhibited the pulmonary accumulation of leukocytes and eosinophils in rats, which is parallel to the decrease of IL4 , IL-5, TNF- $\alpha$, and sICAM- 1 in serum and overexpression of ICAM-1 and HO-1 in allergic lung tissue (Figure 7). Our study is similar to previous reports and consistent with reports of increased ICAM-1 expression in the lungs of patients with asthma [97]. Cell count analyses and histological results corroborate the positive correlations of the inflammatory cells of BALF with the extent of total inflammatory cells, eosinophil, lymphocyte, and macrophage infiltration in lung tissues and BALF. In this study, the inhibitory effect of RN on inflammation in allergic rats was accompanied by a significant decrease in Th2 cytokines, sICAM-1, and ICAM-1 overexpression. Our results suggest that RN may play a key role in blocking the recruitment of leukocytes and eosinophils in lung through Th2-cytokines dependent pathway, much as dexamethasone.

As expected, DXM, one of the most potent corticosteroids, also suppressed antigen-induced AHR and eosinophilic inflammation in this model. However unlike RN, DXM suppressed Th1 responses (IFN- $\gamma$ ) as well as Th2 (IL-4, IL-5, and TNF- $\alpha$ ) responses. In this study, the administration of $\mathrm{RN}$ resulted in a downregulation of the Th2 cytokines IL- 4 , IL- 5 , and TNF- $\alpha$; however, there was significant concomitant increase in the levels of the Th1 cytokine IFN- $\gamma$ in serum. In addition, IFN- $\gamma$ levels were higher in the RN group than those in the model group or Normal group. This type of immunoregulation may prove to be more beneficial than Th1 cytokines (IFN- $\gamma$ and IL12) or Thl adjuvant therapy, which may cause undesirable inflammation because of higher-than-normal levels of Th1 


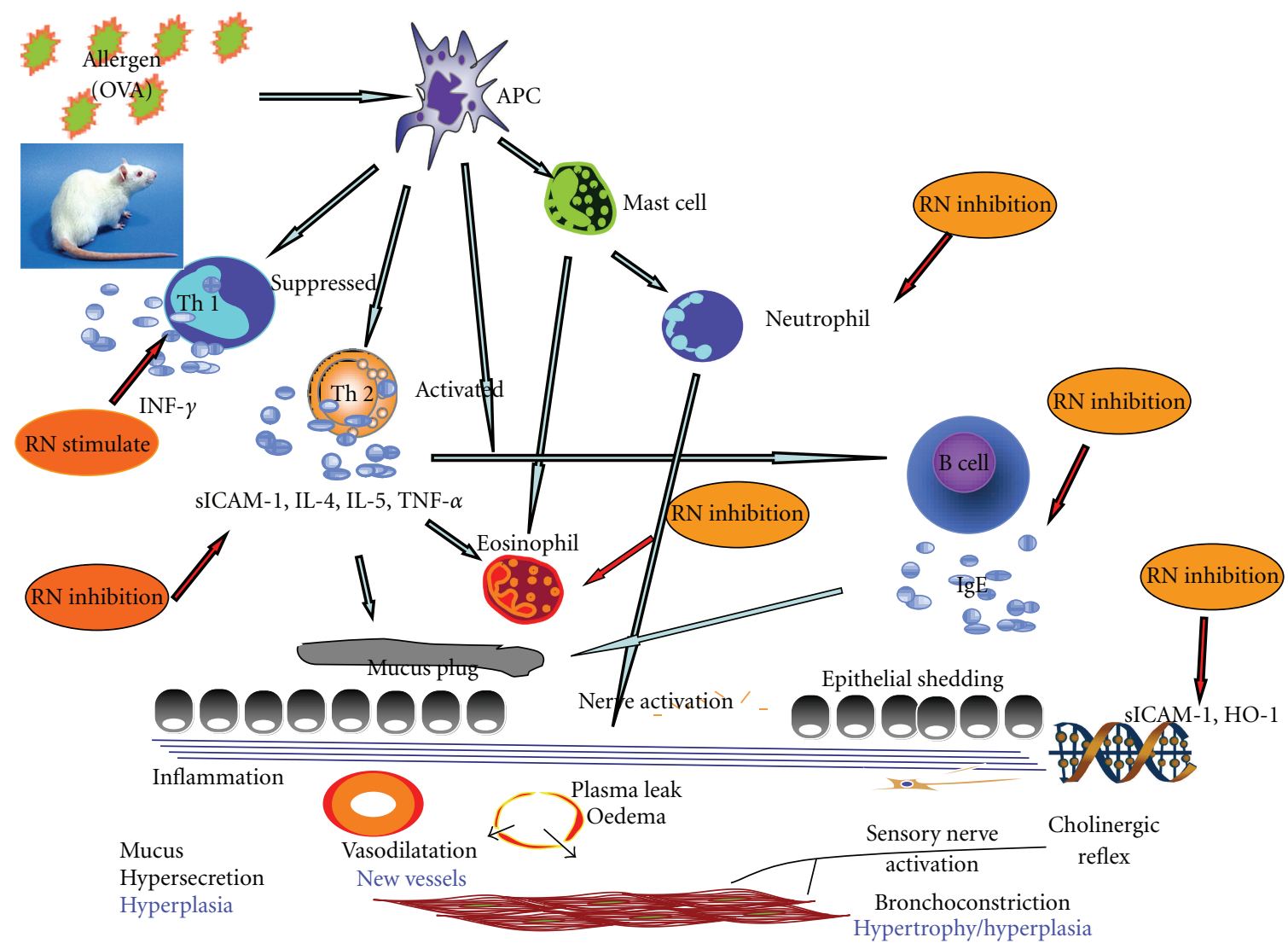

FIGURE 7: Main anti-inflammatory and immunoregulatory targets of Ravan Napas (RN) in allergic asthma. This figure illustrates the cascade of activations and inactivations resulting from exposure to allergen after sensitization in asthma, from exposure of Antigen-presenting cells (APC) to activation of mast cells and neutrophils, activation of Th2 cells liberating ICAM, interleukins, and TNF $\alpha$, inactivation of Th1 cells releasing INF $\gamma$, and so forth. From the results reported, RN, as indicated, acts on various pathways implicated in the bronchial response to antigens: stimulation of Th1, inactivation of Th2, decreased ICAM and HO-1 expression, decreased IgE production, and decreased recruitment of neutrophils and other inflammatory cells.

cytokines. These findings suggest that $\mathrm{RN}$ and perhaps other antiasthma formulas may offer some clinical advantages over corticosteroids because they are less likely to increase the patient's susceptibility to infection.

Oxidative stress is thought to induce the inflammation of many chronic diseases [98]. During asthma, reactive oxygen species (ROS) - including superoxide anion-is produced in tissues, from oxidative injury [24]. One of these defence mechanisms is the induction of a stress-response protein, HO-1. HO-1 catalyses the initial and rate limiting step of heme metabolism. In asthma attacks, since the activity and protein synthesis of $\mathrm{HO}-1$ are greatly increased, its products, bilirubin, free iron, and $\mathrm{CO}$ would also be increased [99, 100]. CO can act as second messenger [101]. Although studies suggest a cytoprotective effect of $\mathrm{HO}-1$, its overexpression might also contribute to asthma inflammation. The following mechanism might be involved: $\mathrm{HO}-1$ and $\mathrm{CO}$ accelerate the release of proinflammatory mediators such as IL-5 and TNF- $\alpha$ in mast cells and eosinophils thus increasing the hyperresponsiveness of the airways [102]. Bilirubin, if produced excessively, would disturb the biomembrane. Free iron, if it accumulates, could become cytotoxic. So we can assume that during asthma, HO-1 has dual effects [103]. We also found that low levels of HO-1 expression are protective. Moderate levels of expression decrease its cytoprotective effect, whereas high expression actually worsens the damage. The experimental results showed that the expression of HO1 was significantly higher in the model than in the control group. Interestingly, similar results have been reported with extracts from plats close to those used in $\mathrm{RN}[32,33]$.

In conclusion, RN suppressed antigen-induced inflammation in this rat model of asthma. This effect was accompanied by reduction of leukocytes, eosinophilic inflammation, and specific downregulation of Th2 responses, inhibiting the expression of ICAM-1 and HO-1 in lung tissue. This study suggests that Uighur herbal medicines, such as RN, should be further explored for possible use for treatment of asthma and allergy.

\section{Acknowledgments}

The authors express their deep sense of gratitude to Professor Dr. Brigitte Winklehner for her encouragement and support. The authors are also thankful to Eurasia-Pacific Uninet 
(EPU) financial support, as Post Doc Research Fellowship to Dr. Nurmuhammat Amat. This study was funded internally by the Medical University of Xinjiang.

\section{References}

[1] M. Masoli, D. Fabian, S. Holt, and R. Beasley, "The global burden of asthma: executive summary of the GINA Dissemination Committee Report," Allergy, vol. 59, no. 5, pp. 469478, 2004.

[2] J. Rees and J. Price, "Asthma in children: prevalence and prospects for prevention," in ABC of Asthma, pp. 35-37, BMJ, London, UK, 3rd edition, 1997.

[3] P. J. Barnes, "New aspects of asthma," Journal of Internal Medicine, vol. 231, no. 5, pp. 453-461, 1992.

[4] T. W. Rall, "Drugs used for the treatment of asthma," in The Pharmacological Basis of Therapeutics, A. Goodman-Gilman, Ed., pp. 618-637, McGraw-Hill, Oxford, UK, 8th edition, 1990.

[5] C. E. Brightling, F. A. Symon, S. S. Birring, P. Bradding, I. D. Pavord, and A. J. Wardlaw, "TH2 cytokine expression in bronchoalveolar lavage fluid $\mathrm{T}$ lymphocytes and bronchial submucosa is a feature of asthma and eosinophilic bronchitis," Journal of Allergy and Clinical Immunology, vol. 110, no. 6, pp. 899-905, 2002.

[6] W. W. Busse and L. J. Rosenwasser, "Mechanisms of asthma," Journal of Allergy and Clinical Immunology, vol. 111, supplement 3, pp. S799-S804, 2003.

[7] K. F. Chung and P. J. Barnes, "Role of inflammatory mediators in asthma," British Medical Bulletin, vol. 48, no. 1, pp. 135-148, 1992.

[8] S. J. Levine, "Bronchial epithelial cell-cytokine interactions in airway inflammation," Journal of Investigative Medicine, vol. 43, no. 3, pp. 241-249, 1995.

[9] S. Finotto, I. Ohno, J. S. Marshall et al., "TNF- $\alpha$ production by eosinophils in upper airways inflammation (nasal polyposis)," Journal of Immunology, vol. 153, no. 5, pp. 2278-2289, 1994.

[10] M. Lampinen, M. Carlson, L. D. Håkansson, and P. Venge, "Cytokine-regulated accumulation of eosinophils in inflammatory disease," Allergy, vol. 59, no. 8, pp. 793-805, 2004.

[11] R. Mueller, P. Chanez, A. M. Campbell, J. Bousquet, C. Heusser, and G. R. Bullock, "Different cytokine patterns in bronchial biopsies in asthma and chronic bronchitis," Respiratory Medicine, vol. 90, no. 2, pp. 79-85, 1996.

[12] F. Phillip, "Gene therapy for asthma," Molecular Therapy, vol. 7, pp. 148-152, 2003.

[13] S. Romagnani, "The role of lymphocytes in allergic disease," Journal of Allergy and Clinical Immunology, vol. 105, no. 3, pp. 399-408, 2000.

[14] J. Bousquet, P. K. Jeffery, W. W. Busse, M. Johnson, and A. M. Vignola, "Asthma: from bronchoconstriction to airways inflammation and remodeling," American Journal of Respiratory and Critical Care Medicine, vol. 161, no. 5, pp. 17201745, 2000.

[15] G. J. Gleich, "Mechanisms of eosinophil-associated inflammation," Journal of Allergy and Clinical Immunology, vol. 105, no. 4, pp. 651-663, 2000.

[16] R. Pauwels, "The relationship between airway inflammation and bronchial hyperresponsiveness," Clinical and Experimental Allergy, vol. 19, no. 4, pp. 395-398, 1989.

[17] H. Renz, K. Bradley, J. Saloga, J. Loader, G. L. Larsen, and E. W. Gelfand, "T cells expressing specific $\mathrm{V} \beta$ elements regulate immunoglobulin E production and airways responsiveness in vivo," Journal of Experimental Medicine, vol. 177, no. 4, pp. 1175-1180, 1993.

[18] M. Wills-Karp, "Immunologic basis of antigen-induced airway hyperresponsiveness," Annual Review of Immunology, vol. 17, pp. 255-281, 1999.

[19] C. D. Wegner, R. H. Gundel, P. Reilly, N. Haynes, L. G. Letts, and R. Rothlein, "Intercellular adhesion molecule-1 (ICAM1) in the pathogenesis of asthma," Science, vol. 247, no. 4941, pp. 456-459, 1990.

[20] N. D. Manolitsas, C. J. Trigg, A. E. McAulay et al., "The expression of intercellular adhesion molecule- 1 and the $\beta 1$ integrins in asthma," European Respiratory Journal, vol. 7, no. 8, pp. 1439-1444, 1994.

[21] A. M. Vignola, A. M. Campbell, P. Chanez et al., "HLADR and ICAM-1 expression on bronchial epithelial cells in asthma and chronic bronchitis," American Review of Respiratory Disease, vol. 148, no. 3, pp. 689-694, 1993.

[22] B. Mo, Z. Zhang, Y. Xu, W. Xiong, X. A. Liu, and G. Zhen, "Expression of heme oxygenase-1 in the peripheral blood mononuclear cells from asthmatic patients," Journal of Huazhong University of Science and Technology. Medical Sciences, vol. 25, no. 4, pp. 385-388, 2005.

[23] I. Rahman, D. Morrison, K. Donaldson, and W. MacNee, "Systemic oxidative stress in asthma, COPD, and smokers," American Journal of Respiratory and Critical Care Medicine, vol. 154, no. 4, part 1, pp. 1055-1060, 1996.

[24] J. E. Repine, A. Bast, and I. Lankhorst, "Oxidative stress in chronic obstructive pulmonary disease," American Journal of Respiratory and Critical Care Medicine, vol. 156, no. 2, part 1, pp. 341-357, 1997.

[25] O. Kitada, T. Kodama, K. Kuribayashi et al., "Heme oxygenase-1 (HO-1) protein induction in a mouse model of asthma," Clinical and Experimental Allergy, vol. 31, no. 9, pp. 1470-1477, 2001.

[26] K. A. Nath, A. Agarwal, and B. Vogt, "Functional consequences of induction of heme oxygenase," in Contemporary Issues in Nephorology Acute Renal failure: Emerging Concepts and Therapeutic Strategies, M. S. Goligorsky, Ed., pp. 97-118, Churchill Livingston, New York, NY, USA, 1995.

[27] O. Kitada, "Expression of heme oxygenase-1 and its effects in allergic airway inflammation and hyperresponsiveness," Japanese Journal of Allergology, vol. 51, no. 11, pp. 1095-1102, 2002.

[28] H. Wang, H. Li, and J. Pan, "The expression and regulation of heme oxygenase- 1 in asthmatic guinea pigs," Zhonghua Jie He He Hu Xi Za Zhi, vol. 22, no. 10, pp. 605-609, 1999.

[29] S. E. Wenzel and R. Covar, "Update in asthma 2005," American Journal of Respiratory and Critical Care Medicine, vol. 173, no. 7, pp. 698-706, 2006.

[30] H. Upur and A. Yusup, Modern Study of Body Temperament and Fluids Theory of Uighur Medicine, vol. 132, Publishing House of Xinjiang Scientific Technique, 2003.

[31] H. Upur, N. Amat, and A. Yusup, "The study on immunoregulation effect of zhihan pingchuan granulars on mice," Journal of Medicine \& Pharmacy of Chinese Minorities, vol. 17, pp. 27-29, 2001.

[32] M.-Y. Lee, J.-E. Yuk, O.-K. Kwon et al., "Anti-inflammatory and anti-asthmatic effects of Viola mandshurica W. Becker (VM) ethanolic (EtOH) extract on airway inflammation in a mouse model of allergic asthma," Journal of Ethnopharmacology, vol. 127, no. 1, pp. 159-164, 2010.

[33] H.-H. Shen, K. Wang, W. Li et al., "Astragalus Membranaceus prevents airway hyperreactivity in mice related to Th2 
response inhibition," Journal of Ethnopharmacology, vol. 116, no. 2, pp. 363-369, 2008.

[34] Y.-K. Yim, H. Lee, K.-E. Hong et al., "Anti-inflammatory and immune-regulatory effects of subcutaneous perillae fructus extract injections on OVA-induced asthma in mice," Evidence-Based Complementary and Alternative Medicine, vol. 7, no. 1, pp. 79-86, 2010.

[35] Y.-C. Lee, J.-C. Lee, Y.-B. Seo, and Y.-B. Kook, "Liriopis tuber inhibit OVA-induced airway inflammation and bronchial hyperresponsiveness in murine model of asthma," Journal of Ethnopharmacology, vol. 101, no. 1-3, pp. 144-152, 2005.

[36] J. Ra, S. Lee, H. J. Kim, Y. P. Jang, H. Ahn, and J. Kim, "Bambusae Caulis in Taeniam extract reduces ovalbumininduced airway inflammation and T helper 2 responses in mice," Journal of Ethnopharmacology, vol. 128, no. 1, pp. 241247, 2010.

[37] E. J. Yang, J.-S. Lee, C.-Y. Yun et al., "Inhibitory effects of Duchesnea chrysantha extract on ovalbumin-induced lung inflammation in a mouse model of asthma," Journal of Ethnopharmacology, vol. 118, no. 1, pp. 102-107, 2008.

[38] E. R. Secor Jr., W. F. Carson IV, A. Singh et al., "Oral bromelain attenuates inflammation in an ovalbumin-induced murine model of asthma," Evidence-Based Complementary and Alternative Medicine, vol. 5, no. 1, pp. 61-69, 2008.

[39] C. H. Shih, T. J. Huang, C. M. Chen, Y. L. Lin, and W. C. Ko, "S-petasin, the main sesquiterpene of petasites formosanus, inhibits phosphodiesterase activity and suppresses ovalbumin-induced airway hyperresponsiveness," EvidenceBased Complementary and Alternative Medicine. In press.

[40] T. Nagai, M. Nakao, Y. Shimizu, Y. Kodera, M. Oh-Ishi, and T. Maeda, "Proteomic analysis of anti-inflammatory effects of a Kampo (Japanese herbal) medicine "sho-seiryuto (xiao-qing-long-tang)" on airway inflammation in a mouse model," Evidence-Based Complementary and Alternative Medicine. In press.

[41] G. P. Lu, D. J. Cui, and Y. J. Guo, "Introducing a new experimental method of developing asthmatic rat model," Zhonghua Jie He He Hu Xi Za Zhi, vol. 18, pp. 377-378, 1995.

[42] P. Ablizl, Y. Cong, M. Musa, Y. Zhu, and R. Kasimu, "Chemical composition of the essential oil of Hyssopus cuspidatus from Xinjiang, China," Chemistry of Natural Compounds, vol. 45, no. 3, p. 445, 2009.

[43] A. R. Bilia, M. Fumarola, S. Gallori, G. Mazzi, and F. F. Vincieri, "Identification by HPLC-DAD and HPLC-MS analyses and quantification of constituents of fennel teas and decoctions," Journal of Agricultural and Food Chemistry, vol. 48, no. 10, pp. 4734-4738, 2000.

[44] J. Kitajima, T. Ishikawa, Y. Tanaka, M. Ono, Y. Ito, and T. Nohara, "Water-soluble constituents of fennel. V. Glycosides of aromatic compounds," Chemical and Pharmaceutical Bulletin, vol. 46, no. 10, pp. 1587-1590, 1998.

[45] J. Kitajima, T. Ishikawa, and Y. Tanaka, "Water-soluble constituents of fennel. II. Four erythro-anethole glycol glycosides and two p-hydroxyphenylpropylene glycol glycosides," Chemical and Pharmaceutical Bulletin, vol. 46, no. 10, pp. 1591-1594, 1998.

[46] J. Kitajima, T. Ishikawa, and Y. Tanaka, "Water-soluble constituents of fennel. I. Alkyl glycosides," Chemical and Pharmaceutical Bulletin, vol. 46, no. 10, pp. 1643-1646, 1998.

[47] T. Ishikawa, J. Kitajima, and Y. Tanaka, "Water-soluble constituents of fennel. III. Fenchane-type monoterpenoid glycosides," Chemical and Pharmaceutical Bulletin, vol. 46, no. 10, pp. 1599-1602, 1998.
[48] T. Ishikawa, Y. Tanaka, J. Kitajima, and Y. Ida, "Watersoluble constituents of fennel. VIII. Monoterpenoid alcohols and thujane-, camphane-, norfenchane-type monoterpenoid glycosides," Chemical and Pharmaceutical Bulletin, vol. 47, no. 6, pp. 805-808, 1999.

[49] J. Kitajima, T. Ishikawa, Y. Tanaka, and Y. Ida, "Constituents of fennel. X. New chromanone and phenylethanoid glycosides, and threo-epoxyanethole," Chemical and Pharmaceutical Bulletin, vol. 47, no. 10, pp. 1448-1450, 1999.

[50] M. Ono, Y. Ito, J. Kinjo, S. Yahara, T. Nohara, and Y. Niiho, "Four new glycosides of stilbene trimer from Foeniculi Fructus (fruit of Foeniculum vulgare Miller)," Chemical and Pharmaceutical Bulletin, vol. 43, no. 5, pp. 868-871, 1995.

[51] M. Ono, Y. Ito, T. Ishikawa et al., "Five new monoterpene glycosides and other compounds from Foeniculi Fructus (fruit of Foeniculum vulgare MILLER)," Chemical and Pharmaceutical Bulletin, vol. 44, no. 2, pp. 337-342, 1996.

[52] S. de Marino, F. Gala, N. Borbone et al., "Phenolic glycosides from Foeniculum vulgare fruit and evaluation of antioxidative activity," Phytochemistry, vol. 68, no. 13, pp. 1805-1812, 2007.

[53] N. Koyama, K. Kuribayashi, T. Seki et al., "Serotonin derivatives, major safflower (Carthamus tinctorius L.) seed antioxidants, inhibit Low-Density Lipoprotein (LDL) oxidation and atherosclerosis in apolipoprotein E-deficient mice," Journal of Agricultural and Food Chemistry, vol. 54, no. 14, pp. 4970-4976, 2006.

[54] E. O. Kim, K. T. Lee, and S. W. Choi, "Chemical comparison of germinated-and ungerminated-safflower (Carthamus tinctorius) seeds," Journal of the Korean Society of Food Science and Nutrition, vol. 37, no. 9, pp. 1162-1167, 2008.

[55] KH. M. Ahmed, M. S. Marzouk, E. A. M. El-Khrisy, S. Abdel Wahab, and S. S. El-Din, "A new flavone diglycoside from Carthamus tinctorius seeds," Pharmazie, vol. 55, no. 8, pp. 621-622, 2000.

[56] M. Taveira, F. Fernandes, P. Guedes de Pinho, P. B. Andrade, J. A. Pereira, and P. Valentão, "Evolution of Brassica rapa var. rapa L. volatile composition by HS-SPME and GC/IT-MS," Microchemical Journal, vol. 93, no. 2, pp. 140-146, 2009.

[57] M. Tomoda, H. Asahara, R. Gonda, and K. Takada, "Constituents of the seed of Malva verticillata. VIII. Smith degradation of MVS-VI, the major acidic polysaccharide, and anti-complementary activity of products," Chemical and Pharmaceutical Bulletin, vol. 40, no. 8, pp. 2219-2221, 1992.

[58] N. Shimizu, H. Asahara, M. Tomoda, R. Gonda, and N. Ohara, "Constituents of the seed of Malva verticillata. VII. Structural features and reticuloendothelial systempotentiating activity of MVS-I, the major neutral polysaccharide," Chemical and Pharmaceutical Bulletin, vol. 39, no. 10, pp. 2630-2632, 1991.

[59] X. Zhang, H.-B. Xiao, X.-Y. Xue, Y.-G. Sun, and X.-M. Liang, "Simultaneous characterization of isoflavonoids and astragalosides in two Astragalus species by high-performance liquid chromatography coupled with atmospheric pressure chemical ionization tandem mass spectrometry," Journal of Separation Science, vol. 30, no. 13, pp. 2059-2069, 2007.

[60] C. Chu, H. -X. Cai, M. -T. Ren et al., "Characterization of novel astragaloside malonates from Radix Astragali by HPLC with ESI quadrupole TOF MS," Journal of Separation Science, vol. 33, no. 4-5, pp. 570-581, 2010.

[61] Q. B. Han, J. Z. Song, C. F. Qiao, L. Wong, and H.-X. $\mathrm{Xu}$, "Preparation isolation of cyclolanostane-type saponins from Astragalus membranaceus Bge. var. mongholicus (Bge.) 
Hsiao by TLC-MS/MS guided high-speed counter-current chromatography," Journal of Separation Science, vol. 30, no. 1, pp. 135-140, 2007.

[62] Y.-Y. Bian, J. Guan, Z.-M. Bi, Y. Song, and P. Li, "Studies on chemical constituents of Astragalus membranaceus (Fisch. ) Bge. var. mongholicus (Bge.) Hsiao," Chinese Pharmaceutical Journal, vol. 41, no. 16, pp. 1217-1221, 2006.

[63] D.-H. Yu, Y.-M. Bao, C.-L. Wei, and L.-J. An, "Studies of chemical constituents and their antioxidant activities from Astragalus mongholicus Bunge," Biomedical and Environmental Sciences, vol. 18, no. 5, pp. 297-301, 2005.

[64] P.-C. Wang, Z.-Y. Zhang, J. Zhang, and T.-J. Tong, “Two isomers of HDTIC isolated from Astragali Radix decrease the expression of p16 in 2BS cells," Chinese Medical Journal, vol. 121, no. 3, pp. 231-235, 2008.

[65] A. Subarnas, Y. Oshima, and H. Hikino, "Isoflavans and a pterocarpan from Astragalus mongholicus," Phytochemistry, vol. 30, no. 8, pp. 2777-2780, 1991.

[66] N. Shimizu, M. Tomoda, M. Kanari, and R. Gonda, "An acidic polysaccharide having activity on the reticuloendothelial system from the root of Astragalus mongholicus," Chemical and Pharmaceutical Bulletin, vol. 39, no. 11, pp. 2969-2972, 1991.

[67] Q. Yan, Z. Jiang, S. Yang, W. Deng, and L. Han, "A novel homodimeric lectin from Astragalus mongholicus with antifungal activity," Archives of Biochemistry and Biophysics, vol. 442, no. 1, pp. 72-81, 2005.

[68] S. Guo, J.-A. Duan, Y. Tang et al., "High-performance liquid chromatography-two wavelength detection of triterpenoid acids from the fruits of Ziziphus jujuba containing various cultivars in different regions and classification using chemometric analysis," Journal of Pharmaceutical and Biomedical Analysis, vol. 49, no. 5, pp. 1296-1302, 2009.

[69] S. Guo, Y.-P. Tang, J.-A. Duan, S.-L. Su, and D.-W. Qian, "Chemical constituents from the fruits of Ziziphus jujuba," Chinese Journal of Natural Medicines, vol. 7, no. 2, pp. 115118, 2009.

[70] S. Guo, Y. P. Tang, J. A. Duan, S. L. Su, and A. W. Ding, "Two new terpenoids from fruits of Ziziphus jujuba," Chinese Chemical Letters, vol. 20, no. 2, pp. 197-200, 2009.

[71] A. M. Pawlowska, F. Camangi, A. Bader, and A. Braca, "Flavonoids of Zizyphus jujuba L. and Zizyphus spina-christi (L.) Willd (Rhamnaceae) fruits," Food Chemistry, vol. 112, no. 4, pp. 858-862, 2009.

[72] J. Yu, Z. Dai, and R. Lin, "Chemical constituents of Viola tianshanica," Zhongguo Zhongyao Zazhi, vol. 34, no. 22, pp. 2916-2917, 2009.

[73] L. Bielory and K. Lupoli, "Herbal interventions in asthma and allergy," Journal of Asthma, vol. 36, no. 1, pp. 1-65, 1999.

[74] K. H. Hsieh, "Evaluation of efficacy of traditional Chinese medicines in the treatment of childhood bronchial asthma: clinical trial, immunological tests and animal study. Taiwan Asthma Study Group," Pediatric Allergy and Immunology, vol. 7, no. 3, pp. 130-140, 1996.

[75] N. Savithramma, Ch. Sulochana, and K. N. Rao, "Ethnobotanical survey of plants used to treat asthma in Andhra Pradesh, India," Journal of Ethnopharmacology, vol. 113, no. 1, pp. 54-61, 2007.

[76] M. P. Sheehan, M. H.A. Rustin, D. J. Atherton et al., "Efficacy of traditional Chinese herbal therapy in adult atopic dermatitis," The Lancet, vol. 340, no. 8810, pp. 13-17, 1992.

[77] K. Amin, D. Lúdvíksdóttir, C. Janson et al., "Inflammation and structural changes in the airways of patients with atopic and nonatopic asthma," American Journal of Respiratory and Critical Care Medicine, vol. 162, no. 6, pp. 2295-2301, 2000.

[78] L. Maddox and D. A. Schwartz, "The pathophysiology of asthma," Annual Review of Medicine, vol. 53, pp. 477-498, 2002.

[79] T. Fukuda, Y. Fukushima, T. Numao et al., "Role of interleukin-4 and vascular cell adhesion molecule-1 in selective eosinophil migration into the airways in allergic asthma," American Journal of Respiratory Cell and Molecular Biology, vol. 14, no. 1, pp. 84-94, 1996.

[80] R. A. Pauwels, G. J. Brusselle, and J. C. Kips, "Cytokine manipulation in animal models of asthma," American Journal of Respiratory and Critical Care Medicine, vol. 156, no. 4, part 2, pp. S78-S81, 1997.

[81] D. S. Robinson, Q. Hamid, S. Ying et al., "Predominant $\mathrm{T}_{\mathrm{H} 2}$-like bronchoalveolar T-lymphocyte population in atopic asthma," The New England Journal of Medicine, vol. 326, no. 5, pp. 298-304, 1992.

[82] D. S. Robinson, S. Ying, A. M. Bentley et al., "Relationships among numbers of bronchoalveolar lavage cells expressing messenger ribonucleic acid for cytokines, asthma symptoms, and airway methacholine responsiveness in atopic asthma," Journal of Allergy and Clinical Immunology, vol. 92, no. 3, pp. 397-403, 1993.

[83] P. S. Foster, S. P. Hogan, A. J. Ramsay, K. I. Matthaei, and I. G. Young, "Interleukin 5 deficiency abolishes eosinophilia, airways hyperreactivity, and lung damage in a mouse asthma model," Journal of Experimental Medicine, vol. 183, no. 1, pp. 195-201, 1996.

[84] J. E. de Vries, J.-F. Gauchat, G. G. Aversa, J. Punnonen, H. Gascan, and H. Yssel, "Regulation of IgE synthesis by cytokines," Current Opinion in Immunology, vol. 3, no. 6, pp. 851-858, 1991.

[85] U.-A. Temann, B. Prasad, M. W. Gallup et al., "A novel role for murine IL-4 in vivo: induction of MUC5AC gene expression and mucin hypersecretion," American Journal of Respiratory Cell and Molecular Biology, vol. 16, no. 4, pp. 471478, 1997.

[86] F. Sabatini, M. Silvestri, R. Sale et al., "Fibroblast-eosinophil interaction-modulation of adhesion molecules expression and chemokine release by human fetal lung fibroblasts in response to IL-4 and TNF- $\alpha$," Immunology Letters, vol. 84, no. 3, pp. 173-178, 2002.

[87] M. Ebisawa, B. S. Bochner, S. N. Georas, and R. P. Schleimer, "Eosinophil transendothelial migration induced by cytokines. I. Role of endothelial and eosinophil adhesion molecules in IL- $1 \beta$-induced transendothelial migration," Journal of Immunology, vol. 149, no. 12, pp. 4021-4028, 1992.

[88] J. Lefort, M.-A. Nahori, C. Ruffié, B. B. Vargaftig, and M. Pretolani, "In vivo neutralization of eosinophil-derived major basic protein inhibits antigen-induced bronchial hyperreactivity in sensitized guinea pigs," Journal of Clinical Investigation, vol. 97, no. 4, pp. 1117-1121, 1996.

[89] S. Montefort, W. R. Roche, P. H. Howarth et al., "Intercellular adhesion molecule-1 (ICAM-1) and endothelial leucocyte adhesion molecule-1 (ELAM-1) expression in the bronchial mucosa of normal and asthmatic subjects," European Respiratory Journal, vol. 5, no. 7, pp. 815-823, 1992.

[90] N. Takahashi, M. C. Liu, D. Proud, X.-Y. Yu, S. Hasegawa, and E. W. Spannhake, "Soluble intracellular adhesion molecule 1 in bronchoalveolar lavage fluid of allergic subjects following segmental antigen challenge," American Journal of Respiratory and Critical Care Medicine, vol. 150, no. 3, pp. 704-709, 1994. 
[91] A. Kokuludağ, A. Sin, E. Terzioğlu, G. Saydam, and F. Sebik, "Elevation of serum eosinophil cationic protein, soluble tumor nec1rosis factor receptors and soluble intercellular adhesion molecule-1 levels in acute bronchial asthma," Journal of Investigational Allergology and Clinical Immunology, vol. 12, no. 3, pp. 211-214, 2002.

[92] Y. C. Lee, K. T. Cheon, and Y. K. Rhee, "Changes of soluble ICAM-1 levels in serum and bronchoalveolar lavage fluid from patients with atopic bronchial asthma after allergen challenge," Journal of Asthma, vol. 34, no. 5, pp. 405-412, 1997.

[93] M.-C. Seminario and G. J. Gleich, "The role of eosinophils in the pathogenesis of asthma," Current Opinion in Immunology, vol. 6, no. 6, pp. 860-864, 1994.

[94] J. J. Costa, P. F. Weller, and S. J. Galli, "The cells of the allergic response: mast cells, basophils, and eosinophils," Journal of the American Medical Association, vol. 278, no. 22, pp. 18151822, 1997.

[95] A. L. Wardlaw, "Molecular basis for selective eosinophil trafficking in asthma: a multistep paradigm," Journal of Allergy and Clinical Immunology, vol. 104, no. 5, pp. 917-926, 1999.

[96] J. Douwes, P. Gibson, J. Pekkanen, and N. Pearce, "Noneosinophilic asthma: importance and possible mechanisms," Thorax, vol. 57, no. 7, pp. 643-648, 2002.

[97] R. H. Gundel, C. D. Wegner, C. A. Torcellini, and L. G. Letts, "The role of intercellular adhesion molecule-1 in chronic airway inflammation," Clinical and Experimental Allergy, vol. 22, no. 5, pp. 569-575, 1992.

[98] R. Djukanovic, W. R. Roche, J. W. Wilson et al., "Mucosal inflammation in asthma," American Review of Respiratory Disease, vol. 142, no. 2, pp. 434-457, 1990.

[99] A. M. K. Choi and J. Alam, "Heme oxygenase-1: function, regulation, and implication of a novel stress-inducible protein in oxidant-induced lung injury," American Journal of Respiratory Cell and Molecular Biology, vol. 15, no. 1, pp. 919, 1996.

[100] R. Stocker, A. N. Glazer, and B. N. Ames, "Antioxidant activity of albumin-bound bilirubin," Proceedings of the National Academy of Sciences of the United States of America, vol. 84, no. 16, pp. 5918-5922, 1987.

[101] M. D. Maines, "The heme oxygenase system: a regulator of second messenger gases," Annual Review of Pharmacology and Toxicology, vol. 37, pp. 517-554, 1997.

[102] Z. Dong, Y. Lavrovsky, M. A. Venkatachalam, and A. K. Roy, "Heme oxygenase-1 in tissue pathology: the Yin and Yang," American Journal of Pathology, vol. 156, no. 5, pp. 1485-1488, 2000.

[103] D. M. Suttner and P. A. Dennery, "Reversal of HO-1 related cytoprotection with increased expression is due to reactive iron," The FASEB Journal, vol. 13, no. 13, pp. 1800-1809, 1999. 


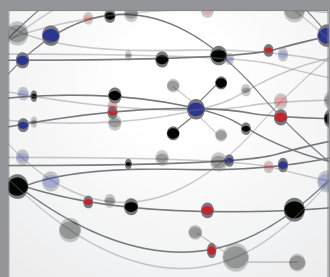

The Scientific World Journal
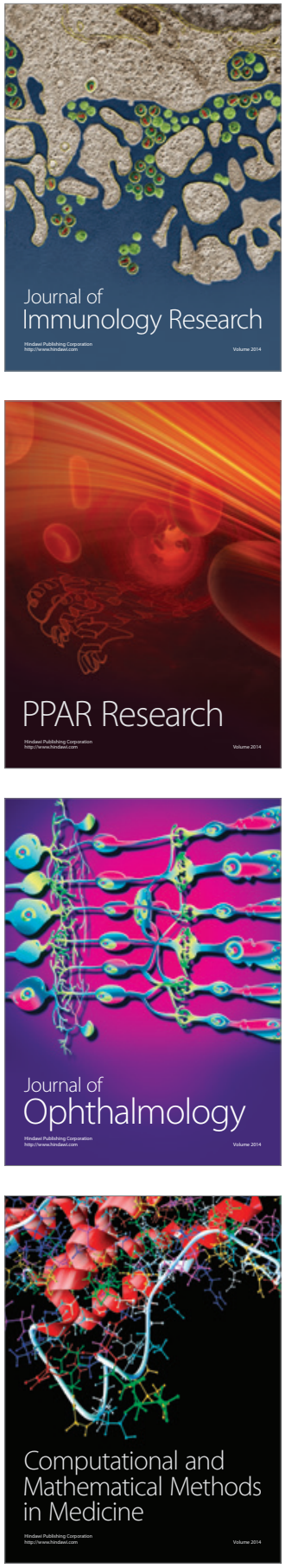

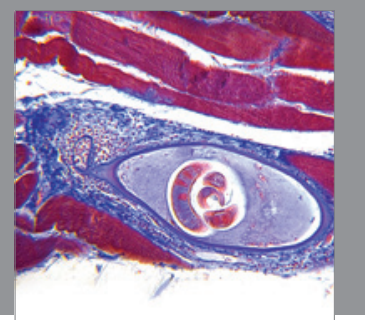

Gastroenterology

Research and Practice
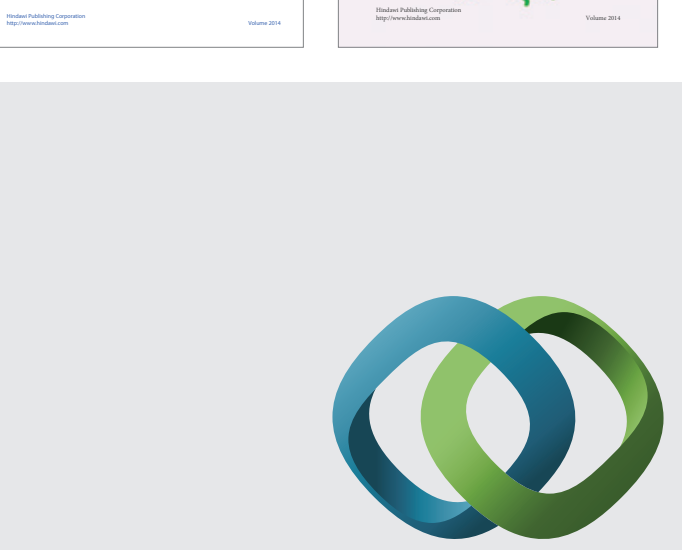

\section{Hindawi}

Submit your manuscripts at

http://www.hindawi.com
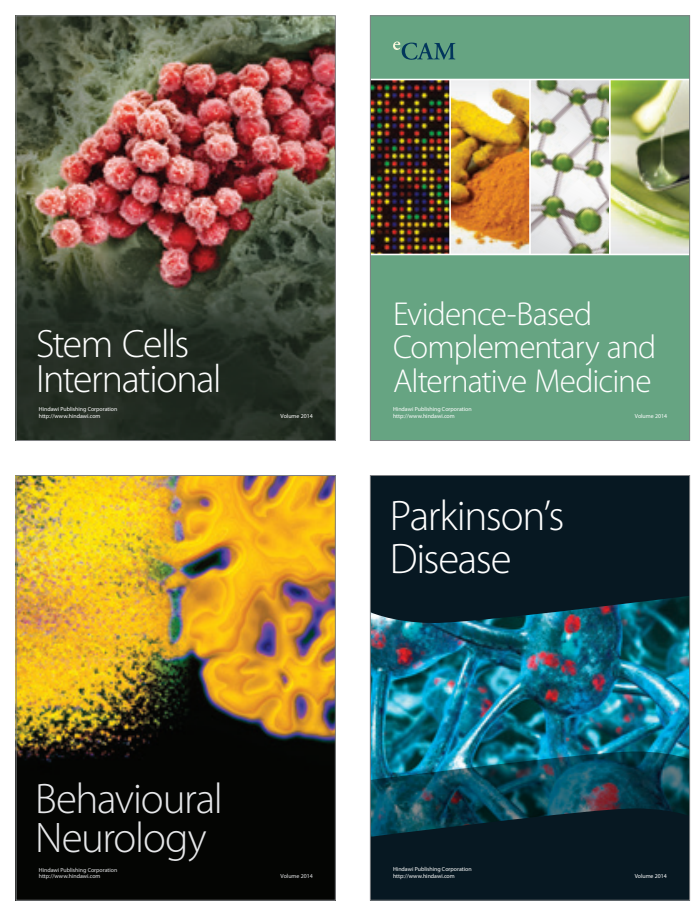

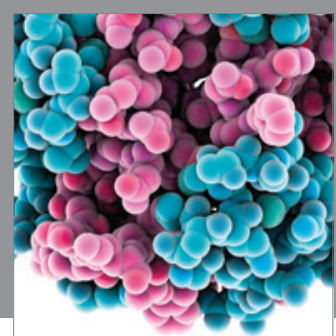

Journal of
Diabetes Research

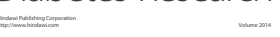

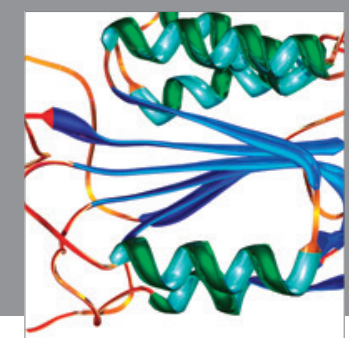

Disease Markers
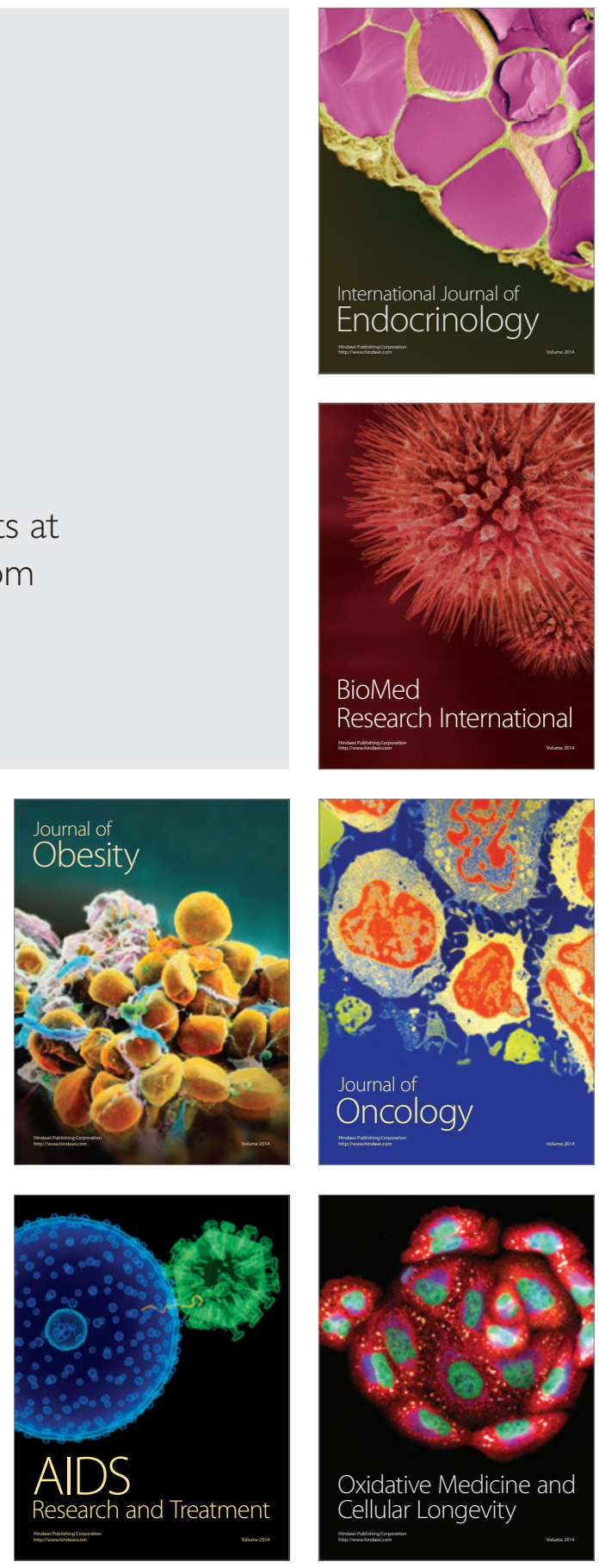